\title{
Sucesión dinástica y legitimidad episcopal en la Mérida visigoda
}

\author{
Dynastic succession and Episcopal Legitimacy in Visigoth Mérida
}

\author{
Pablo Fuentes Hinojo \\ IES San Cristóbal de los Ángeles. Madrid \\ pfuenteshinojo@gmail.com
}

\section{RESUMEN}

Este artículo pretende analizar, a partir de las Vitas Patrum Emeritensium, texto hagiográfico del siglo VII, varios aspectos problemáticos relacionados con las elecciones de obispos, la emergencia de dinastías sacerdotales, y la gestión patrimonial de las iglesias diocesanas en la Hispania visigoda. Se intenta, así mismo, definir algunas de las claves del proceso de construcción material y simbólica de la legitimidad del obispo como gobernante de la ciudad cristiana. Todo ello complementando las noticias procedentes de las Vitas con testimonios extraídos de fuentes cronísticas, actas conciliares y códigos de legislación civil.

Palabras clave: Reino visigodo. Imperio romano. Mérida. Toledo. Paulo. Fide. Masona. Legitimidad episcopal. Sucesión dinástica. Vitas Patrum Emeritensium.

\begin{abstract}
Based on the Vitas Patrum Emeritensium, a seventh-century hagiographical text, this article analyzes problematic aspects related to the election of bishops, the emergence of priestly dynasties, and the patrimonial management of diocesan churches in Visigoth Spain. It likewise aims to define some of the keys to the process of material and symbolic construction of the bishop's legitimacy as leader of the Christian city. Testimony extracted from chronicles, council acts and codes of civil law complements the news proceeding from the Vitas.
\end{abstract}

Key words: Visigothic kingdom. Roman Empire. Mérida. Toledo. Paulus. Fidel. Masona. Dynastic succession. Episcopal legitimacy. Vitas Patrum Emeritensium.

Sumario: 1. Las Vitas Patrum Emeritensium en su contexto histórico. 2. Elecciones episcopales en el mundo tardorromano y visigodo. 3. Orígenes y ascenso de una familia sacerdotal bizantina: el episcopado de Paulo de Mérida. 4. Sucesión y conflicto: el episcopado de Fidel de Mérida. 
Las Vitas Sanctorum Patrum Emeritesium, obra hagiográfica ambientada en la Mérida del siglo VI, constituyen una de las fuentes más importantes para el conocimiento de la vida urbana y eclesial en la Hispania visigoda. El texto se organiza en cinco opuscula o pequeñas obras semiindependientes. El primero se halla dedicado a Augusto, un servidor del monasterio de santa Eulalia; el segundo a un monje intemperante del monasterio de Cauliana; y el tercero al abad de origen norteafricano Nancto, que se estableció en Mérida en la década de 570. El núcleo central de la obra lo constituyen los opúsculos cuarto y quinto, en los que se narra la vida de los obispos Paulo, Fidel y Masona, bajo cuyos pontificados la ciudad alcanzó su máximo esplendor. El de éste último conforma el relato más largo, terminando con una breve referencia a los obispos que le sucedieron, Inocencio y Renovato. Aunque la obra se centra en sucesos locales, acaecidos en Mérida y su entorno, la riqueza de detalles sobre la vida ceremonial y litúrgica de la ciudad, las constantes referencias a los conflictos sociales de la época, y la presencia de personajes, como Masona, que tuvo un papel protagonista en los principales acontecimientos del reinado de Leovigildo (569-586) y Recaredo (586-601), hacen de ella un documento de valor inestimable. Particular interés reviste el material, que servirá de base a este artículo, referido a la sucesión y legitimidad del obispo y a su papel como gobernante de la ciudad cristiana. El relato literario refleja diversos aspectos problemáticos, relacionados con la elección del obispo, el surgimiento de dinastías sacerdotales y la gestión patrimonial de las iglesias, que arrojan luz y complementan las noticias procedentes de las actas conciliares.

\section{LAS VITAS PATRUM EMERITENSIUM EN SU CONTEXTO HISTÓRICO}

La utilización de cualquier texto hagiográfico por parte del historiador exige de una previa aproximación a su estudio crítico. Las Vitas Patrum Emeritensium cuentan con un cuidado trabajo sobre su transmisión manuscrita, obra de Antonio Maya Sánchez para la nueva edición del Corpus Christianorum ${ }^{1}$. A partir del mismo, el autor establece la existencia de dos recensiones de la obra. La primera de ellas, correspondiente a la redacción original, recogida en dos códices visigóticos, el de San Millán de la Cogolla y el de santo Domingo de Silos, así como en algunos fragmentos, fue compuesta según parece durante el episcopado de Esteban (633-638) por un diácono anónimo de Mérida. La segunda redacción, concluida entre 670 y 680, en tiempos del obispo Festo, nos ha sido transmitida por varios manuscritos, entre los que cabría destacar el de la Biblioteca Nacional de Lisboa, el del Archivo Catedralicio de Segorbe y el de la Biblioteca Municipal de Évreux. Contiene varias interpolaciones y, probablemente, se debe a la mano de un tal Paulo, diácono de la misma iglesia.

Como se ha señalado, el núcleo central de la obra lo constituyen las vidas de los obispos Paulo, Fidel, Masona, Inocencio y Renovato, que ocuparon la cátedra emeritense entre los años 540 y 633 aproximadamente. La producción de vidas de obispos constituye uno de los géneros literarios más prolíficos de la Antigüedad tardía y el alto Medievo. Por lo general, se trababa de breves notas biográficas, que incluían información sobre los orígenes, actividad intelectual, obras piadosas y portentos, rea-

\footnotetext{
${ }^{1}$ VPE, ed. A. Maya Sánchez, CCh., Series Latina, CXVI, Brepols, Turnhout, 1992.
} 
lizados por un obispo ya fallecido. Solían agruparse en colecciones más o menos extensas de vidas de prelados de la misma sede, a menudo escritas por uno de sus sucesores o bien por encargo de éste a algún clérigo de la diócesis. El poeta de origen italiano Venancio Fortunato compuso, a requerimiento de ciertos obispos galos, una serie de obras en honor de prelados, que les habían precedido en el cargo ${ }^{2}$. Este tipo de literatura desempeñó un importante papel propagandístico, asociado a la transmisión y continuidad del poder eclesiástico. El prelado que escribía o encargaba la redacción del texto estaba afirmando la existencia de una cadena ininterrumpida de gobernantes religiosos, que conectaba a todos los obispos de la sede desde su fundación, a menudo fechada en época apostólica, hasta el día del Juicio Final. Sus virtudes revertían sobre el obispo que los conmemoraba, reforzando su prestigio y autoridad. El metropolitano Ildefonso de Toledo, particularmente sensible a este hecho, dedicó siete de las trece vidas De Viris Illustribus a prelados que le habían precedido en la cátedra de su iglesia ${ }^{3}$. Aunque el obispo actual no fuese más que un eslabón de la cadena de pastores, que debían de conducir al pueblo cristiano a la salvación, el poder que le había sido conferido en el momento de su ordinatio no se extinguía con la muerte; sino que se proyectaba generación tras generación a través de sus sucesores. Papel semejante a las vidas de obispos jugaron los discursos pronunciados por el titular de la diócesis con motivo del aniversario de los sepelios de sus predecesores difuntos, así como las inscripciones de sus sarcófagos y lápidas sepulcrales ${ }^{4}$. El epitafio de Juan de Tarragona (469-519), el de su sucesor Sergio (519-554)5, o el de Juan de Zaragoza (619-631) ${ }^{6}$, encargado por su hermano, Braulio, al archidiácono Eugenio, constituyen un excelente testimonio del valor legitimador que entrañaban estos textos?

Puede afirmarse, sin lugar a dudas, que los opúsculos cuarto y quinto de las Vitas Patrum Emeritensium pertenecen al género de las vidas de obispos. Como se expuso arriba, fueron redactados en Mérida durante la década de 630, con toda probabilidad por encargo del metropolitano Esteban a un clérigo anónimo de su diócesis. En opinión de Roger Collins, su autor no sólo pretendía reforzar la autoridad del obispo comitente y el prestigio de la sede metropolitana, sino también justificar sus aspiraciones a un primado de honor, que a comienzos del siglo VII le disputaba Toledo ${ }^{8}$. Cuando se llevó a cabo esta primera redacción de las Vitas, Mérida era todavía una ciudad importante, orgullosa de su pasado, del poder e influencia de sus obispos y, sobre todo, de contar con el principal centro de peregrinación del reino, la cellae memoriae de santa Eulalia. Pero su posición comenzaba a verse minada por el ascenso de Toledo. Durante la época romana, los obispos de esta iglesia habían sido simples sufragáneos de la provincia Carthaginensis. Su encumbramiento se inició a princi-

${ }^{2}$ Ven. Fort. Carm. IV, I-X, ed. F. Leo, MGH, AA, Berlín, 1881.

3 Hildeph. De Vir. Illustr. II, III, V, VII, VIII, XIII, XIV, ed. J. P. Migne, PL, 96, París, 1862, cols. 198-206.

${ }^{4}$ Février, P.-A., "La mort chrétienne”, XXXIII Settimana di Spoleto, 1987, pp. 881-942.

5 Vives, J., Inscripciones cristianas de la España romana y visigoda, Barcelona, 1969, $\mathrm{n}^{\circ}$ 277-278.

${ }^{6}$ Eug. Tol. Carm. XXI, ed. F. Vollmer, MGH, AA, 14, Berlín, 1905.

7 Martin, C., "La commémoration des évêques en Espagne wisigothique", Autour des morts: mémorie et identité, ed. O. Demoulin, Ruan, 2001, pp. 369-375.

8 Collins, R., "Merida and Toledo: 550-585", ed. E. James: Visigothic Spain: New Approaches. Oxford, 1980, pp. 189-219. 
pios el siglo VI. Ya en 527, décadas antes de que los reyes visigodos instalasen su corte en la ciudad, las actas del concilio II de Toledo muestran que habían logrado sustraerse a la jurisdicción de la sede metropolitana de Carthago Spartaria (Cartagena), asumiendo el primado de una nueva provincia de Carpetania et Celtiberiae, desgajada de la Carthaginensis ${ }^{9}$. Con la ocupación en 552 del sureste peninsular por las tropas del emperador Justiniano (527-565), la escisión se consolidó. Al quedar la costa de la Carthaginensis junto con su sede metropolitana bajo dominio imperial, los obispos de Toledo intentaron extender su jurisdicción sobre todas las sedes episcopales del interior de la provincia, en manos de los godos. Este movimiento suscitó las protestas de algunos prelados, para quienes la autoridad del metropolitano de Toledo se circunscribía a la región central de la Carthaginensis, la llamada Carpetania, y el resto de los obispados de la provincia debían permanecer sujetos a la sede de Carthago Spartaria. A fin de vencer su resistencia, la iglesia de Toledo buscó el respaldo de las autoridades civiles. En 610, el rey Gundemaro (610-612), recién llegado al trono, promovió la celebración de un sínodo en Toledo, donde reclamó para la cátedra de esta ciudad, ahora capital de la monarquía católica, el honor del primado de todas las iglesias de la Carthaginensis, rechazando de plano las demandas de los obispos que defendían los derechos de la sede de Carthago Spartaria. La asamblea se clausuró con la promulgación de un decreto regio, subscrito por todos los metropolitanos del reino, que reconocía a Toledo como única metrópoli de la Carthaginensis $^{10}$. Tras la expulsión de los bizantinos en 624, aquella parte del territorio conquistado, que en otros tiempos había pertenecido a la provincia Carthaginensis, quedó bajo la jurisdicción eclesiástica del metropolitano de Toledo. Carthago Spartaria, arrasada por las tropas del rey Suintila (621-631), se vio completamente privada de sus antiguas prerrogativas y honores.

En este contexto de encumbramiento de la cátedra toledana se llevo a cabo la primera redacción de las Vitas Patrum Emeritensium. El clérigo encargado de la tarea narró la historia de los obispos que habían regido la sede primada de la provincia de Lusitania, durante el último siglo, concentrando su atención en el pontificado de Masona y en el enfrentamiento que éste mantuvo con el rey Leovigildo. A comienzos de la década de 630, se trataba ya de un episodio lejano, que sin duda el autor reelaboró, incidiendo en sus aspectos religiosos, de acuerdo con la tradición de la iglesia de Mérida, hasta convertirlo en uno de los puntos culminantes del conflicto entre catolicismo y arrianismo. La figura de Masona, protagonista incuestionable del relato, se perfila como el campeón de la fe. Para construir esta imagen literaria fue preciso eludir toda referencia a uno de los hechos políticos en que se vio envuelto el personaje histórico, la rebelión del príncipe Hermenegildo contra su padre Leovigildo, a la cual brindó su apoyo la ciudad Mérida entre los años 579 y $582^{11}$. Dada la identificación

9 Vives, J., Concilios visigóticos e hispano-romanos, Barcelona-Madrid, 1963, p. 51.

10 Para texto integro del decreto de Gundemaro y la constitución sinodal que lo refrenda, véase Vives, Concilios, pp. 403-410.

${ }^{11}$ En su empeño por borrar toda huella de compromiso con el rebelde, el autor de las Vitas alteró incluso un fragmento extraído de GREG. Dial. III, 31: "Recaredus rex non patrem perfidum, sed fratrem martyrem secutus, ab Ariana pravitate conversus, totam quoque Wisigothorum gentem ita ad veram perduxit fidem" (ed. G. Waitz, $M G H$, SRL, Hannover, 1878, p. 636), sustituyendo las palabras fratrem martyrem por Christum Dominum (VPE V, IX, 4). 
existente entre el obispo y su iglesia, el esfuerzo por hacer de Masona una víctima de la persecución religiosa de Leovigildo, sólo podía tener el propósito de destacar el papel de la sede emeritense durante la querella arriana, presentándola como centro de la ortodoxia nicena, frente a un Toledo contaminado por la herejía. La disputa entre obispo y monarca por la posesión de la túnica de santa Eulalia, momento álgido del quinto opúsculo, constituye un trasunto de la rivalidad por el primado entre ambas sedes, cuya resolución dependía en última instancia del patrocinio de la mártir. Mérida, custodia de sus reliquias, estimaba que le correspondía esa dignidad ${ }^{12}$.

La pugna por el primado acabaría resolviéndose en favor de la sede regia. La culminación del proceso llegó en 681, cuando el metropolitano de Toledo obtuvo de los padres reunidos en el XII concilio general el reconocimiento de la facultad de consagrar en su iglesia a los obispos de todas las provincias, una vez que el rey hubiese elegido al candidato idóneo ${ }^{13}$. De este modo, la organización eclesiástica del reino alcanzó su máximo grado de centralización, con el metropolitano de Toledo a la cabeza. Por la misma época, el diácono Paulo concluyó la segunda redacción de las Vitas Patrum Emeritensium, posiblemente siguiendo instrucciones del obispo Festo. La recuperación de la obra, compuesta medio siglo antes, parece asociada a un programa de restauración del prestigio de la iglesia emeritense, muy mermado en los últimos tiempos. Sólo el sepulcro de santa Eulalia, en torno al cual giran muchos de los relatos incluidos en las Vitas, continuaba atrayendo a peregrinos de todos los rincones del reino ${ }^{14}$. Festo, consciente del declive de su autoridad frente al metropolitano de Toledo, no pudo por menos que interesarse en una obra, que destacaba la relación privilegiada que habían mantenido los obispos de Mérida con su santa patrona, y del que ahora él era el principal garante.

\section{ELECCIONES EPISCOPALES EN EL MUNDO TARDORROMANO Y VISIGODO}

En la Iglesia de los siglos IV al VII, la elección del obispo recaía sobre el clero y el pueblo de su diócesis; pero, puesto que la comunidad formaba parte de la Iglesia universal, se requería también la aprobación de todos los prelados de la provincia. Tres de ellos debían trasladarse al lugar donde iba a escogerse nuevo obispo, para supervisar el proceso, otorgar su consentimiento y oficiar la ceremonia de imposición de manos u ordinatio, con el permiso por escrito de todos sus colegas. La confirmación, de que se había procedido de acuerdo con la disciplina canónica, correspondía al metropolitano u obispo de la capital de la provincia ${ }^{15}$. Cuando había consenso y los

${ }^{12}$ Collins, R.: art cit., pp. 189-219.

13 Conc.XII Tol. VI, Vives, Concilios, pp. 393-394.

14 Vit. Fruct. 11, ed. M. C. Díaz y Díaz, La vida de san Fructuoso de Braga, Braga, 1974, p. 99, narra un viaje de Fructuoso a Mérida, que suele fecharse en torno a 652, "ob desiderium egregiae virginis Eulaliae". Del contexto, se desprende, que en la época en que fue redactada la obra, hacia los años 670-680, el sepulcro de la mártir seguía siendo un importante centro de peregrinación. Corrobora este hecho la fundación hacia 661 de un monasterio de vírgenes, dirigido por la abadesa Eugenia, en el mismo santuario. Véase, Vives, Inscripciones, $\mathrm{n}^{\circ} 358$.

${ }^{15}$ Conc. I Nic. IV, ed. J. D. Mansi, SC, II, Florencia, 1759, cols. 669-670. 
obispos provinciales consideraban que el candidato era digno de recibir el honor del episcopado, todo marchaba bien. Pero, si no se cumplía alguno de estos requisitos, pronto surgían desavenencias. Lo habitual era que se solventasen mediante un debate ordenado o, en caso extremo, apelando a la intervención del metropolitano. Las atribuciones de éste en materia de elección de obispos, reconocidas por el concilio de Nicea de 325 , parecen haberse consolidado en la primera mitad del siglo V. El papa León I (440-461), en una epístola dirigida a su vicario en Tesalónica, recomienda que, a falta de consenso, el metropolitano elija al candidato más digno ${ }^{16}$. Hacia 451, un sínodo celebrado en Arlés estableció que, en caso de controversia en la elección de un obispo, el metropolitano se inclinase a favor de quien hubiese recibido mayor número de $\operatorname{votos}^{17}$. Poco a poco, la autoridad del metropolitano se reforzó con nuevos requerimientos. Así, en 516, un sínodo celebrado en Tarragona dispuso que los obispos que no hubiesen sido ordenados en la sede primada de la provincia, debían obtener la aprobación por escrito del metropolitano y acudir a visitarle en el plazo de dos meses ${ }^{18}$.

La salida a elecciones controvertidas no siempre era pacifica. A veces, estallaba la tensión en forma de disputas entre familias o grupos influyentes, que aspiraban a colocar en la cátedra episcopal a uno de sus miembros. En tales casos, la aceptación del sufragio popular era síntoma inequívoco de que ninguna de las facciones rivales tenía bastante fuerza, para imponer a su propio candidato. También podía ocurrir que se produjese una doble elección, lo que invariablemente daba lugar a un cisma en la comunidad. Durante el período en que ésta permanecía escindida, cada facción impugnaba la legitimidad del obispo elegido por la otra, casi siempre en medio de una lucha tumultuosa por el control de los principales centros litúrgicos de la ciudad. Amiano Marcelino describe el conflicto que sostuvieron en 366 Dámaso y Ursino por la cátedra de Roma. Después de un enfrentamiento en la basílica de Sicinino, fueron retirados ciento treinta y siete cadáveres ${ }^{19}$. Los informes que el prefecto Símaco remitió a Rávena en 418, sobre la lucha que sostenían Bonifacio y Eulalio por sede romana, reflejan las problemas que tenían las autoridades para mantener el orden público en tales circunstancias ${ }^{20}$.

De todos modos, este tipo de conflictos no eran frecuentes. De las veinticinco elecciones a la sede romana que tuvieron lugar entre 311 y 530, sólo cinco derivaron en cisma. Por lo común, se llegaba a un consenso. Lo que resulta complicado es determinar quiénes participaban en el debate. Las fuentes se refieren a menudo al clerus et plebs como cuerpo electoral, pero rara vez ofrecen detalles sobre su composición. Lo más seguro es que el término clerus se emplease para designar al conjunto de presbíteros y diáconos de la sede vacante. Definir lo que se entendía por plebs no es tan

${ }^{16}$ Leo Ep. XIV, V, Migne, PL, 54, París, 1846, cols. 615-616.

17 Conc. II Arel. V, Mansi, SC, VII, Florencia, 1762, col. 879.

${ }^{18}$ Conc. Tarr. V, Vives, Concilios, p. 35.

19 Amm. Marcel. Res Gestae. XXVII, 3, 12-13, ed. y trad, ingl. J. C. Rolfe, Loeb Classical Libray, 3 vols., Cambridge, Mass.-Londres, 1935-1940; Coll. Avell. 1, 7, ed. O. Guenther, Epistolae Imperatorum Pontificum Aliorum Inde ab a. CCCLXVII usque DLIII datae Avellana Quae Dicitur Collectio, CSEL, 35, 1, Praga-Viena-Leipzig, 1895.

${ }^{20}$ Para la documentación oficial sobre el desarrollo del conflicto, véase Coll. Avell. 14-37. 
sencillo. Durante el siglo IV, parece que hacía referencia a todos los laicos. Sinesio de Cirene describe cómo en las comunidades rurales de Hydrax y Palaebisca solía congregarse todo el pueblo, incluidas las mujeres, para elegir al nuevo obispo ${ }^{21}$. Práctica que pudo observar de nuevo durante una visita a la aldea de Olbia $^{22}$. En Gaza, donde los cristianos eran aún una minoría, clérigos y laicos deliberaban conjuntamente ${ }^{23}$. Incluso en grandes ciudades como Roma, el populus Romanus ${ }^{24}$, la plebs sancta ${ }^{25}$, o la plebs fidelis ${ }^{26}$ tomaba parte activa en la elección del obispo. Es sólo a partir del pontificado de Bonifacio I (418-422) que se introduce la fórmula clerus, ordo et plebs ${ }^{27}$ o clerus, honorati, ordo et plebs ${ }^{28}$, para definir el cuerpo de electores. Su uso sistemático denota que, para esta época, el pueblo ya no desempeñaba otro papel que el de aprobar con sus aclamaciones la elección del clero local y los notables.

Lentamente, se había ido deslizando la idea de que la participación de los laicos en las elecciones episcopales era motivo de disturbios y violencia. Un sínodo provincial, reunido en Laodicea hacia mediados de la década de 360, había llegado incluso a decretar que no se permitiese a la plebe escoger a los obispos ${ }^{29}$. Medio siglo después, los únicos laicos que tenían voz y voto en las elecciones episcopales eran los miembros de la curia urbana y los grandes terratenientes, que pertenecían en su mayoría a la aristocracia senatorial. Pero a ojos de los eclesiásticos, ni siquiera éstos se hallaban libres de crítica. Ennodio de Pavía, en un discurso dedicado al obispo Lorenzo de Milán, señala que, aunque su elección se había caracterizado por el consenso, esto no podía considerarse un título de alabanza, "pues el favor del pueblo cambia a menudo de manera repentina y la turba de los senadores, que nada sabe de reflexiones, sino que se deja arrebatar por la pasión, ama a los desconocidos" ${ }^{\prime 30}$

A veces, la dificultad no estribaba tanto en la falta de acuerdo, como en la baja calidad moral de los aspirantes. Sidonio Apolinar, obispo de Clermont, refiere el caso de unas elecciones celebradas hacia 469 en Chalon-sur-Saône (Cabillonum), a las que concurrieron tres candidatos: un aristócrata de vida disoluta, un hombre que basaba sus esperanzas en las generosas dádivas repartidas entre su clientela, y un tercero que había prometido tierras de la Iglesia a quien le respaldase. Como consecuencia, el pueblo se escindió en tres facciones, cuyas rivalidades se vieron enardecidas por intrigas privadas. Finalmente, el metropolitano, Paciente de Lyon, rechazó a los tres postulantes, y persuadió al clero y al pueblo, para que eligiesen al archidiácono Juan, hombre de vida honesta ${ }^{31}$. En Oriente las autoridades eclesiásticas intentaron solventar este tipo de situaciones, fijando con detalle el procedimiento a seguir. Al quedar

${ }^{21}$ Syn. Ep. LXVII, 76, Migne, $P G$, 66, París, 1859, cols. 1412-1415.

22 Ibid. LXXVI, Migne,. $P G, 66$, col. 1442.

${ }^{23}$ Marc. Diac. Vit. Porph. 11, ed. B. G. Teubner, Leipzig, 1895, pp. 11-12.

${ }^{24}$ Coll. Avell. 1, 2-3.

25 Ibid. 1,$5 ; 8 ; 10$.

${ }^{26}$ Ibid. $1,6$.

27 Bonif. I Ep. XII, Migne, PL, 20, París, 1845, col. 772-774; Caelest. Ep. IV, 5, Migne, PL, 50, 1846, col.434.

${ }^{28}$ Leo Ep. X, 6, Migne, PL, 54, cols. 633-634.

29 Conc. Laod. XIII, Mansi, SC, II, Florencia, 1759, cols. 565-566.

${ }^{30}$ Enn. Dict. I, 10, ed. F. Vogel, MGH, AA, Berlín, 1885.

31 Sid. Ep. IV, 25, ed. y trad. franc. A., Loyen, Les Belles Lettres, París, 1970. 
una sede vacante, el clero, los curiales y los notables de la ciudad debían seleccionar tres candidatos, de entre quienes el metropolitano elegiría al nuevo obispo. Esta regla, introducida a fines del siglo V, fue confirmada por el emperador Anastasio (591$518)^{32}$ y revalidada en 528 por Justiniano $(527-565)^{33}$. De todos modos, en períodos de controversia religiosa, los emperadores no dudaban en imponer al candidato de la facción que respaldaban, apelando incluso al uso de la fuerza. También intervinieron de manera sistemática en las elecciones de los obispos de Constantinopla, ya fuese para promover sus propios puntos de vista dogmáticos o simplemente llevados por el deseo de acrecentar el prestigio de la capital, encumbrando a su cátedra a un célebre teólogo o a un monje con fama de santidad.

En el Imperio de Occidente y en los reinos bárbaros, que le sucedieron, nunca se estableció un procedimiento eficaz, que permitiese superar las elecciones controvertidas. El progresivo incremento del patrimonio, privilegios y autoridad espiritual de la Iglesia, había hecho del episcopado una dignidad apetecible para la aristocracia romana. Cuando, hacia 460, los notables de la Galia e Hispania cobraron conciencia de la incapacidad del Estado romano para ofrecerles perspectivas de carrera, comenzaron a explorar otras vías para mantener su status. Una de ellas, la más exitosa, consistió en asumir el gobierno de la Iglesia, lo que les permitió mantener su prestigio e influencia en las ciudades ${ }^{34}$. Se inició así un proceso de aristocratización del episcopado. Durante los siguientes doscientos años, auténticas dinastías sacerdotales, dotadas de una amplia capacidad de patrocinio, gobernaron el Occidente postimperial a la manera romana desde sus sedes eclesiásticas. Al lado de ellas, el dominio de los linajes reales germánicos debió parecer transitorio.

No obstante, los monarcas bárbaros comprendieron enseguida que la consolidación de su poder territorial dependía, en buena medida, del control que llegasen a ejercer sobre los obispos ${ }^{35}$. Uno de los métodos que explotaron con mayor asiduidad fue el antiguo privilegio imperial, que otorgaba al soberano facultad para designar prelados. Los reyes merovingios se sirvieron de él como instrumento de patrocinio. Cuando tenían noticia del fallecimiento de un obispo, solían escribir al metropolitano y sus sufragáneos, para comunicarles el nombre de aquél a quien debían consagrar como sucesor en la sede vacante. Por lo general, la elección recaía sobre uno de sus ministros o favoritos, o sobre la persona de algún influyente aristócrata ${ }^{36}$. Hubo reyes que llegaron a poner a la venta obispados ${ }^{37}$. Su actuación, más que erradicar divisiones y enfrentamientos, introdujo un nuevo elemento de competencia en la pugna por alcanzar la dignidad episcopal, el logro de la designación regia. Ni siquiera un hombre del rango de Gregorio de Tours, descendiente de una familia senatorial galo-

${ }^{32}$ Sev. Ant. Ep. I, 18; 30; 39, 46, ed. y trad. ingl. E. W. Brooks, The Sixth Book of the Select Letters of Severus Patriarch of Antioch in the Syriac Version of Athanasius of Nisibis, 2 vols., Londres, 19021903

${ }^{33}$ CJ I, III, 41, a. 528, ed. P. Krueger, CJC, II, Berlín, 1877.

${ }^{34}$ Prévot, F.: "Deux fragments de l'épitaphe de Sidoine Apollinare découverts à Clermont-Ferrand", Antiqueté Tardive, I, 1993, pp. 223-229.

${ }_{35}$ Brown, P., El primer milenio de la Cristiandad occidental, Barcelona, 1997, pp. 63-64.

${ }^{36}$ Greg. Tur. Hist. Franc. V, 45, VI, 7, 38, VIII, 20, 22, 39, ed. B. Krusch y W. Levison, MGH, SRM, I.1, Hannover ,1937-1951.

37 Id. Vit. Patr. VI, 3, ed. B. Krusch, MGH, SRM, I.2, Hannover, 1885. 
rromana, cuyos mayores habían ocupado algunas de las sedes más prestigiosas de la $\mathrm{Galia}^{38}$, pudo eludir este requisito. Venancio Fortunato, en un poema compuesto con motivo del adventus o entrada protocolaria de Gregorio en su ciudad episcopal el 28 de agosto de 573, recuerda que éste había sido designado por el rey Sigeberto I de Austrasia (561-575) y su esposa Brunequilda, para suceder en la cátedra turonense a su primo materno Eufronio, recientemente fallecido ${ }^{39}$

La diligencia de los monarcas en la provisión de sedes vacantes contribuyó a crear y reforzar lazos de patrocinio entre la corona y las aristocracias provinciales. Cuando el rey designaba a un noble para ocupar una cátedra, no sólo le brindaba legitimidad y protección, sino también una fuente de riqueza y prestigio social, de la que a menudo se beneficiaba toda su familia. En contrapartida, se esperaba que el nuevo prelado, sus parientes y amigos mostrasen la debida reverencia y fidelidad al monarca. Un sistema no exento de problemas, debido a los limitados medios de acción de la monarquía y al enorme poder que habían llegado a concentrar las aristocracias en el ámbito local y provincial. De hecho, algunos candidatos al episcopado preferían recurrir a la fuerza que les proporcionaban sus propias clientelas, a alianzas con otros nobles o al patrocinio de algún poderoso aristócrata de la región, antes que procurarse la oportuna designación regia.

Tal fue el caso de Albino, gobernador de Provenza, quien, tras cesar en el cargo el año 581, obtuvo el obispado de Uzès con el apoyo de Dinamio, un notable que le había sucedido en la administración provincial. Ninguno de los dos se preocupó por indagar la voluntad del rey Gontrán de Borgoña (561-592), a quien correspondía proveer la sede vacante. Éste no tardó en reaccionar, explotando en beneficio propio las rivalidades de la aristocracia provenzal. Se trataba de una antigua estrategia, consistente en favorecer a una familia frente a otra, a fin de lograr que actuase de acuerdo con los intereses del rey en la zona. Gontrán otorgó la cátedra de Uzès a Jovino, hijo del noble galorromano Aspasio, enemigo de Albino, a quien había precedido en el gobierno de la Provenza. Finalmente, el conflicto se resolvió sin lucha, debido a la inesperada desaparición del obispo Albino, que falleció apenas tres meses después de su elección. El panorama volvería a complicarse en el transcurso de aquel mismo año, cuando Jovino apoyase una demanda de justicia presentada por el obispo Teodoro de Marsella ante el rey Childeberto II de Austrasia (575-595), con quien Gontrán mantenía una disputa por la diócesis masiliense. Esta vez el monarca se sirvió del gobernador Dinamio, para promover la elección de un candidato rival a la sede de Uzès en la persona del diácono Marcelo, hijo del senador Félix, un poderoso aristócrata de la región. El nuevo prelado, atento al consejo de Dinamio, convocó a los obispos provinciales y se hizo consagrar, requisito que Jovino había pasado por alto. Cuando éste quedó libre puso cerco a Uzès, en un intento de hacer valer sus derechos por la

38 Gregorio era hijo de Florencio, senador romano de Clermont, y de su esposa Armentaria, sobrina del obispo Nicetio de Lyon y nieta de dos ilustres aristócratas, Florentino, senador de Génova, y Gregorio, obispo de Langres. Miembros de la rama paterna de la familia habían ocupado las sedes episcopales de Clermont, Tours y Arlés, y por parte materna monopolizaban las de Lyon y Langres; cfr. Greg. Tur. Hist. Franc. IV, 15; Glor. Martyr. 83; Vit. Mart. I, 35; Vit. Patr. II, 2; VIII, ed. B. Krusch, MGH, SRM, I.2, Hannover, 1885.

${ }^{39}$ Venan. Fort. Carm. V, 3, 15-16. 
fuerza de las armas; si bien poco después aceptó la compensación económica que le ofrecía Marcelo a cambio de su renuncia a la cátedra episcopal ${ }^{40}$.

Ningún texto canónico describe el sistema de nombramiento de obispos seguido en Hispania bajo los últimos tiempos del Imperio y los primeros de la monarquía visigoda. Testimonios indirectos apuntan a que se mantuvo la elección por el pueblo y el clero, tal y como establecían los cánones de Nicea. No obstante, en ocasiones se produjeron desviaciones a la norma, o ésta se aplicó de manera poco rigurosa, como recuerdan las amonestaciones dirigidas por los papas Inocencio I (401-417) ${ }^{41}$, Hilario (461-468) $)^{42}$ y Hosmisdas (514-523) ${ }^{43}$ al episcopado hispano. La primera referencia concreta es posterior a la conversión de Recaredo (586-601) y se conserva en las actas del concilio II de Barcelona del año 599, donde se enumeran tres formas de elección: por designación del rey, por aclamación del clero o del pueblo, y por la elección y consentimiento de los obispos. El procedimiento ordinario consistía en presentar al metropolitano y sus sufragáneos dos o tres nombres, escogidos por el clero y el pueblo de la sede vacante, a fin de que los obispos, tras el preceptivo período de ayuno, eligiesen a uno de ellos echando suertes. Este sistema tan sólo reconocía al pueblo y al clero local un derecho de presentación, limitado por la exigencia de que todos los candidatos fueran clérigos de vida irreprehensible, que hubiesen ejercido su ministerio el tiempo fijado por los cánones. Ningún laico, ni siquiera por designación regia, podía acceder a la dignidad episcopal, sin antes pasar por los correspondientes grados eclesiásticos el tiempo establecido en los cánones ${ }^{44}$.

Esta última medida evidencia el rechazo, que experimentaban ciertos miembros de la jerarquía de la Iglesia, hacia la intervención de Recaredo en el nombramiento de obispos. Durante los primeros años de su reinado, el soberano había entregado algunas sedes a ministros y favoritos, carentes de experiencia en oficios eclesiásticos anteriores, por lo que, a menudo, habían actuado de manera imprudente e ilícita. El concilio II de Sevilla, celebrado en 619, recuerda el caso de Agapio de Córdoba, promovido directamente de la vida militar al episcopado en época de Recaredo, y cuya ignorancia de la disciplina canónica le había llevado a delegar en presbíteros la consagración de iglesias, o a deponer de su grado y enviar al exilio a un presbítero, llamado Fragitano, sin previo examen del sínodo provincial ${ }^{45}$. A pesar de todo, durante el siglo VII, se impuso la práctica de que los reyes eligieran a los candidatos,

${ }^{40}$ Greg. Tur. Hist. Franc. IV, 43; VI, 7; 11; Ven, Fort. Carm. VII, 12, 121.

${ }^{41}$ Inoc. I Ep. III, VI, 9, Migne, $P L$, 20, París, 1845, cols. 491-492.

${ }^{42}$ Hil. Ep. 1-3, Migne,. PL, 58, París, 1847, cols. 12-20.

${ }^{43}$ Horm. Ep. 25, Migne, PL, 63, París, 1847, cols. 423-425.

44 Conc. II Barc. III: "Nulli deinceps laicorum liceat ad ecclesiasticos ordines praetermissas canonum prefixa tempora aut per sacra regalía aut per consuetudinem cleri vel plebis vel per electionem assensionemque pontificum ad summum sacerdotium adspirare vel provehi, set cum per canonum conscripta tempora ecclesiasticos per ordinem spirituali opere desuando, probatae vitae adminiculo comitante conscenderit grados, ad summum sacerdotium, si dignitati vita responderit, auctore domino provehatur: ita tamen aut duobus aut tribus quos consensus cleri et plebis selegerit metropolitani iudicio eiusque quoepiscopis praesentatis, quem sors praecunte episcoporum ieiunio, Christo domino terminante mosntraverit, benedictio consecrationis adcumulet; aliter deinceps, quod absit praesunptum, et ordinatores et ordinatos propii honoris depositio subsequatur" (Vives, Concilios, pp. 159-160).

${ }^{45}$ Conc. II Hispal. VI-VII, Vives, Concilios, pp. 166-168. 
ya fuesen eclesiásticos o laicos, que debían ocupar las sedes vacantes. En ocasiones, algún metropolitano oponía resistencia. Tal parece haber sido el caso de Eusebio de Tarragona, a quien Sisebuto (612-621) dirigió una epístola cargada de reproches, exigiéndole que consagrara cuanto antes a su candidato como obispo de Barcelona ${ }^{46}$. Pero en general, el episcopado aceptó las provisiones regias como procedimiento ordinario en materia de elección de obispos. La correspondencia intercambiada el año 632 entre Isidoro de Sevilla y Braulio de Zaragoza sobre el nombramiento del sucesor de Eusebio de Tarragona, recientemente fallecido, demuestra que ambos prelados reconocían el derecho del rey a designar obispos para las sedes vacantes ${ }^{47}$.

Poco tiempo después, en diciembre de 633 , los padres reunidos en el concilio IV de Toledo, con Isidoro de Sevilla a la cabeza, manifestaron su adhesión al sistema niceno, afirmando las prerrogativas del pueblo y el clero local en las elecciones episcopales: "Pero en adelante tampoco será obispo aquel que no hubiere sido elegido por el clero y por el pueblo de la propia ciudad, ni aprobado por la autoridad del metropolitano, y el consentimiento de los obispos de la provincia"48. El mismo canon 19, donde se incluyó esta disposición, recogía una larga lista de impedimentos. No debían ser promovidos al episcopado los convictos de algún delito; los marcados por nota de infamia; los que habían confesado en penitencia pública; los herejes; los bautizados en la herejía o rebautizados, es decir, los conversos al arrianismo; los mutilados por mano propia o ajena, en alusión clara a los eunucos; los casados en segundas nupcias; los que habían tomado por esposa a una viuda, a una mujer repudiada, o a cualquier otra que nos fuese virgen; los que hubiesen tenido concubinas para fornicación; los siervos; los neófitos y seglares; los militares; los curiales; los iletrados; los que no habían cumplido todavía los treinta años; los que no habían pasado por los distintos grados eclesiásticos el tiempo que fijaban los cánones; los que buscaban el cargo mediante intrigas o regalos; y por supuesto los que habían sido nombrados por su antecesor. Sólo después de que se estableciese que el candidato a la dignidad episcopal estaba libre de todos estos impedimentos, y que su vida y doctrina eran recomendables, podría ser consagrado en domingo, con la aprobación del pueblo y el clero de su ciudad, por todos los obispos de la provincia, o al menos por tres; pero con el consentimiento escrito de los ausentes. Para finalizar, el concilio dispuso que, si alguien intentaba alcanzar el episcopado contra la disciplina canónica, sería depuesto junto con los prelados que le hubiesen consagrado.

No parece que estas disposiciones alterasen demasiado el funcionamiento del sistema. En la práctica, los reyes continuaron designando a los candidatos al episcopado para cualquier sede del reino. Ni siquiera las quejas de algunos célebres prelados, como Braulio de Zaragoza, que intentó retener junto a sí a su archidiácono Eugenio, a quien el rey Chindasvinto (642-653) había promovido a la cátedra metropolitana

${ }^{46}$ Siseb. Ep. 6, ed. J. Gil, Miscellanea Wisigothica, Sevilla, 1972, pp. 14-15.

${ }^{47}$ Isid. Ep. XII, 14; XIII, 2, ed. G. B. Ford, Jr., The Letters of St. Isidore of Seville, Amsterdam, 1970, pp. 64; 66.

${ }_{48}$ Conc. IV Tol. XIX: "Sed nec ille deinceps sacerdos ertit, quem nec clerus, nec populus propriae civitatis elegit, vel auctoritas metropolitani vel provincialium sacerdotum assensio exquisivit" (Vives, Concilios, p. 199). 
de Toledo, evitaron que se produjesen actuaciones arbitrarias ${ }^{49}$. El procedimiento ordinario es bien conocido. Cuando moría un obispo, los fieles y el clero elegían un candidato para sucederle y despachaban el oportuno comunicado a la corte, incluyendo probablemente copia de las suggestiones o cartas de presentación remitidas al metropolitano de la provincia. Entre las actas del concilio XII de Toledo del año 681, se han conservado tres ejemplares de este tipo de documentos, enviados por los notables de Mentesa (La Guardia) a su metropolitano, el obispo de Toledo, a fin de que otorgase la cátedra de la ciudad a un tal Emila ${ }^{50}$. Carecen de fecha, aunque todo apunta a que fueron redactadas en el primer tercio del siglo VII. Según G. Martínez Díaz, editor de la colección canónica Hispana, proceden de los archivos toledanos y se incorporaron a la recensión Juliana en tiempos de Ervigio (680-687), para que su formulario sirviera de modelo a futuras propuestas ${ }^{51}$. Las cartas, auténticos libelos suplicatorios, demuestran que los miembros de la iglesia local no ejercían ya más que un derecho de presentación, supeditado a las prerrogativas del metropolitano y el rey.

Éste último era quien solía tomar la decisión final; si bien era costumbre, desatendida por algunos monarcas, consultar con los obispos de la provincia acerca de la idoneidad del candidato, antes de proceder a su designación. Una vez que el rey se pronunciaba, tan sólo restaba que el metropolitano oficiase la consagración del nuevo obispo. El procedimiento era largo y complejo. A la tardanza en comunicar a la corte la muerte del prelado, se sumaban las demoras ocasionadas por las consultas con los obispos comprovinciales, prolongando durante meses el período de vacante, con grave daño para el patrimonio de la iglesia. A fin de abreviar el procedimiento, los padres del concilio XII de Toledo decidieron que, en adelante, fuese el obispo de la capital quien emitiera el iudicium o testimonio de idoneidad sobre el candidato propuesto por el rey, tarea reservada hasta aquel entonces a los obispos comprovinciales. Así mismo atribuyeron al metropolitano de Toledo la facultad de consagrar al elegido, con lo que, a partir de este momento, el titular de la sede regia pasó a desempeñar una función, que la antigua disciplina encomendaba al metropolitano de cada provincia ${ }^{52}$. Como reconocimiento de la primacía de éste, el nuevo prelado debía visitarle en un plazo de tres meses a contar desde su consagración, a fin de recibir las instrucciones oportunas, para gobernar dignamente su iglesia ${ }^{53}$. Con estas medidas, que llevaban a su máximo grado de desarrollo la centralización del sistema de elecciones episcopales, culminó la fase constitutiva del primado toledano ${ }^{54}$.

49 Brau. Ep. XXXI, Migne, $P L$, 80, París, 1863, cols. 677-678.

${ }^{50}$ Vives, Concilios, pp., 409-410.

${ }^{51}$ Martínez Díaz, G., La Colección Canónica Hispana, 3, Madrid, 1966, p. 324.

52 Conc.XII Tol. VI, Vives, Concilios, pp. 393-394.

53 Conc. Emer. IV, Vives, Concilios, p. 328. Este sínodo, celebrado en Mérida el año 666, considera ya usual que la consagración de los obispos elegidos por el rey la oficie un metropolitano distinto al suyo, previa delegación de éste por escrito. Además, constata la obligación que tenía el nuevo prelado de comparecer ante la presencia de su correspondiente metropolitano, para hacer promesa de vivir casta, sobria y rectamente.

54 Rivera Recio, J. F., "Encumbramiento de la sede toledana durante la dominación visigótica", Hispania Sacra, VIII, 1956, pp. 3-34; Orlandis, J. y Ramos Lissón, D., Historia de los concilios de la España romana y visigoda, Pamplona, 1986, pp. 418-419. 


\section{ORÍGENES Y ASCENSO DE UNA FAMILIA SACERDOTAL BIZANTINA: EL EPISCOPADO DE PAULO DE MÉRIDA}

Las Vitas Patrum Emeritensium inician su relato de la historia de los prelados, que gobernaron la sede metropolitana de la Lusitania en el siglo VI, con la figura de Paulo, griego de origen y médico de profesión, que llegado de Oriente se instaló en la ciudad y vivió allí durante largo tiempo antes de alcanzar el episcopado. La cronología de este obispo y de su sobrino y heredero, Fidel, es bastante imprecisa, pues el texto no contiene referencias temporales, y tampoco se conservan actas de ningún sínodo celebrado durante esta época en la provincia de Lusitania. Por la Crónica de Juan de Bíclaro sabemos que el obispo Masona, sucesor de Fidel, ocupaba ya la cátedra de Mérida en el año $573^{55}$. Dato que corrobora la aparición de su nombre, como metropolitano más antiguo del reino, a la cabeza de los signatarios de las actas del concilio III de Toledo ${ }^{56}$. Leandro de Sevilla, que había alcanzado la dignidad episcopal hacia 579 , suscribió el documento en tercer lugar ${ }^{57}$. Eso significa que Masona sucedió a Fidel en una fecha próxima a la que registra el Biclarense y, por lo tanto, este último y su predecesor Paulo debieron gobernar la iglesia de Mérida durante las décadas centrales del siglo VI, probablemente entre los años 530 y 570.

Nada se sabe sobre las razones que impulsaron a Paulo a viajar hasta Mérida e instalarse en la ciudad. Su llegada debió coincidir con el inicio del reinado del Justiniano (527-565) y los primeros tiempos de la restauración imperial en Occidente, cuando las rutas comerciales del Mediterráneo aún mantenían un importante nivel de actividad y era relativamente sencillo desplazarse a través de ellas. De hecho, numerosas ciudades del este y el sur de la península, entre ellas Mérida, contaban con la presencia de comunidades orientales de habla griega, de las que formaban parte mercaderes, como los que en 533 arribaron a la corte de Teudis (531-548), llevando la noticia de la caída de Cartago en manos del general Belisario ${ }^{58}$. Mérida era, además, el centro de peregrinación más importante de Hispania y atraía a gentes venidas de tierras lejanas, como el abad de origen norteafricano Nancto, que hacia el año 570 se asentó en la ciudad por ferviente devoción a santa Eulalia ${ }^{59}$. Es posible que también Paulo llegase a Mérida como peregrino medio siglo antes. Su profesión pudo haberle facilitado el acceso a la iglesia local, que ya debía dispensar a los más necesitados la atención médica, que más tarde reorganizaría y ampliaría Masona. En cualquier caso, no fue el único oriental que figuró en las filas del clero de Mérida. El epitafio griego del diácono Sambacio, que vivió en la ciudad durante del siglo VI, atestigua la

${ }^{55}$ Ioh. Bicl. Chron. a. 573, 8: "Mausona Emeritensis ecclesiae episcopus in nostro dogmate clarus habetur", ed. J. Campos, Juan de Biclaro, obispo de Gerona. Su vida y su obra, CSIC, Madrid, 1960.

56 Vives, Concilios, p. 136.

57 Aunque la historiografía tradicional hace coincidir el inicio del pontificado de Leandro con el estallido de la rebelión de Hermenegildo en 579, Collins, R., art. cit., pp. apunta la posibilidad de que su consagración no se produjese hasta su regreso de su embajada en Constantinopla entre 579 y 582.

58 Proc. De bellis III, 24, 10-12, ed. y trad. ingl. H. B. Dewing, 5 vols., Loeb Classical Library, Cambridge, Mass.-Londres, 1914-1928. Sobre las colonias de comerciantes orientales en Hispania, véase García Moreno, L. A., "Colonias de comerciantes orientales en la Península Ibérica: s. V-VII", Habis, 3, 1972, pp. 127-154.

${ }^{59}$ VPE III, 1. 
presencia en la sede metropolitana de la Lusitania de un grupo, minoritario pero muy influyente, de eclesiásticos de origen greco-oriental ${ }^{60}$.

El movimiento de religiosos y mercaderes bizantinos no se limitó a Hispania, sino que se extendió por todo Occidente, como se desprende de los testimonios de diversos autores de la época. Gregorio de Tours refiere el caso del obispo Simón, que llegó a su ciudad episcopal en 591, huyendo de la destrucción de Antioquía, a causa de un terremoto, $\mathrm{y}$ tras haber pasado algún tiempo como cautivo en la Armenia persa ${ }^{61}$. Ese mismo año, muerto Ragnemodo, obispo de París, y mientras su hermano Faramodo intentaba sucederle en el obispado, cierto Eusebio, comerciante sirio que había realizado numerosas donaciones, fue nombrado en su lugar. Se cuenta que, después de haber aceptado el episcopado, prescindió de todos los asistentes de su predecesor y escogió solamente sirios para el servicio del palacio episcopal ${ }^{62}$.

El autor de las Vitas Patrum Emeritensium no ofrece detalles sobre cómo Paulo llegó a convertirse en obispo, aunque afirma que, tras su ordenación, "Dios erradicó las tormentas de las perturbaciones que habían perturbado a esta misma iglesia en el tiempo de su predecesor" ${ }^{\prime \prime}$. Algunos estudiosos han interpretado estas palabras como una referencia a la agitada situación que se debió vivir en Mérida durante la guerra civil entre Agila (549-554) y Atanagildo (551-567), y al asesinato del primero a manos de sus propios hombres, acaecido en la ciudad, tras haber sido derrotado por su rival con apoyo bizantino ${ }^{64}$. Aunque la hipótesis resulta sugerente, parece más probable que el autor aluda a un conflicto de naturaleza interna, fruto de la ruptura del consensus universorum, en que se basaba el gobierno del obispo sobre su iglesia. Sólo así se entiende la insistencia en presentar la ordenación de Paulo como el instrumento del que se sirvió la providencia, para poner fin a la discordia.

La disciplina canónica no ponía objeciones al nombramiento como obispo de un hombre llegado de otra ciudad. De hecho, hasta bien entrado el siglo IV, ni siquiera era necesario haber pertenecido antes al clero. Progresivamente esta situación fue cambiando. En 343, el concilio de Sárdica prohibió, a instancias de Osio de Córdoba, el nombramiento de obispos que no hubiese servido antes como lector, diácono y presbítero ${ }^{65}$. Y el papa León I dispuso, con motivo de la elección del metropolitano de la provincia de Illyricum, que el nuevo obispo fuese escogido entre los diáconos y presbíteros de su iglesia ${ }^{66}$. Una norma cuyo respeto demandaría a menudo el clero, al que no agradaba que un laico o un forastero frustrase sus expectativas de promoción. Aún así, los seglares continuaron accediendo al gobierno de las sedes eclesiásticas. El impedimento canónico solía ser burlado, confiriendo órdenes menores al candidato

${ }^{60}$ Vives, Inscripciones, $\mathrm{n}^{\mathrm{0}} 418$, datada en el siglo VI por FiTA, F., "Excursiones epigráficas", Boletín de la Real Academia de la Historia, 25, 1894, p. 87.

${ }^{61}$ Greg. Tur. Hist. Franc. X, 24.

${ }^{62}$ Ibid. X, 26.

${ }^{63}$ VPE IV, I, 1: "Multis polleret et humilitate atque benignitate cuetos superaret ei a Domino conlatum est ut predicte ciuitatis promereretur pontificatum. At ubi, elegente Deo, ordinates est episcopus, omnes statim Deus conturbationum procellas, que eadem eclesiam tempore prodecessoris sui conturbuerant, abstulit et nimiam tranquillitatem eclesie sue eius precibus condonauit".

${ }^{64}$ Collins, R., España en la alta Edad Media, 400-1000, Barcelona, 1986, pp. 120-121.

${ }^{65}$ Conc. Sard. X, ed. J. D. Mansi, SC, III, Florencia, 1759, cols. 13-14; 35.

${ }^{66}$ Leo. I Ep. XIV, 6, ed. J. P. Migne, PL, 54, col. 673. 
un día o dos antes de su consagración ${ }^{67}$. Por lo que se refiere a Paulo, ignoramos si ya formaba parte del clero cuando fue elegido obispo. El autor de las Vitas Patrum Emeritensium no hace constar el dato, limitándose a señalar que merecía el episcopado por sus obras de santidad y sus numerosas virtudes. Este argumento justificativo resulta particularmente revelador, ya que en los casos de elecciones disputadas, cuando ninguna de las facciones era capaz de imponer a su pretendiente, solía buscarse como candidato de consenso a un hombre santo, cuya intercesión pusiese fin a la discordia. La mayoría de estos hombres santos -eremitas, monjes o ascetas-, no estaban ordenados y, a menudo, pertenecían a un grupo minoritario dentro de la comunidad, si bien dotado de la suficiente influencia como para respaldar su promoción. Paulo, de origen griego y célebre por su piedad, jugó el papel de intermediario que de él se esperaba. Según el autor de las Vitas, en cuanto fue consagrado obispo cesaron las perturbaciones y, gracias a sus súplicas, Dios "otorgó una tranquilidad extrema a su iglesia" ${ }^{68}$. El restablecimiento del consenssus universorum pone así mismo de relieve el poder que había alcanzado la colonia greco-oriental en Mérida, capaz de mediar entre facciones en pugna y de sentar en la cátedra metropolitana a uno de sus miembros.

Bajo el episcopado de Paulo se establecieron además las bases materiales, sobre las que sus sucesores desarrollarían una gran empresa de patrocinio ${ }^{69}$. Aunque en la ciudad antigua el fenómeno del evergetismo constituía un aspecto más de la actividad patronal, para las comunidades cristianas desempeñó un papel básico, prácticamente desde sus orígenes, como elemento articulador de las relaciones entre sus miembros. A lo largo del primer siglo de la historia del cristianismo, los laicos acomodados actuaron como patronos de las iglesias domésticas, surgidas en las ciudades grecorromanas, permitiendo el uso comunitario de sus propiedades privadas y financiando un eficaz sistema de beneficencia. Sin embargo, a finales del siglo II, la jerarquía eclesiástica emprendió una acción consciente destinada a controlar ese patrocinio privado, de modo que poco a poco los recursos de la comunidad pasaron a canalizarse a través de la figura del obispo. Este cambio no supuso la ruptura de las antiguas redes patronales, sino más bien su integración en un sistema centralizado, que dirigía y supervisaba el clero. Los miembros acomodados de la comunidad siguieron proporcionando la comida y la ropa que se entregaba a las viudas y los huérfanos, las sepulturas donde se enterraba a los pobres, y el dinero que la Iglesia distribuía entre los necesitados; si bien era el obispo, en su calidad de patronus principal, el que decidía cómo, cuándo y a quiénes se brindarían esas prestaciones de acuerdo con un programa, que él mismo diseñaba ${ }^{70}$. Gracias al empleo del lenguaje de la caridad, ni sus actos de beneficencia se percibían como una muestra de orgullo o superioridad social, ni aceptarlos constituía un signo de inferioridad o servilismo.

${ }^{67}$ Just. Nov. VI, 1, 6-7, a. 535, ed. R. Schoell-W. Kroll, CJC, Berlín, 1895, establece, con objeto de acabar con las elecciones fraudulentas, que sólo puedan ser elegidos obispos aquellos que hayan sido clérigos o hayan profesado en al vida monástica al menos seis meses.

${ }^{68} V P E \mathrm{IV}, \mathrm{I}, 1$.

${ }^{69}$ Sobre el patrimonio de la iglesia de Mérida en el siglo VI, véase García Iglesias, L. "Las posesiones de la iglesia emeritense en época visigoda", Gerión, Anejos 2, 1989, pp. 391-402.

70 Daley, B.: "Position and Patronage in the Early Church: The Original Meaning of the Primacy of Honour", Journal of Theological Studies, 44, 1993, pp. 529-553. 
Durante el siglo III, el Estado romano llegó a reconocer a las iglesias locales la capacidad legal de poseer bienes ${ }^{71}$. Tras el fin de la última persecución ${ }^{72}$, los emperadores Constantino y Licinio, reunidos el año 313 en Milán, decidieron colocar al cristianismo en plano de igualdad con las demás religiones, reconociendo a sus iglesias plena personalidad jurídica, y reintegrarles los bienes confiscados, ya obrasen en manos del fisco o hubiesen pasado a las de particulares ${ }^{73}$. Poco después, en 321 Constantino otorgó a la Iglesia el derecho a recibir donaciones y legados testamentarios, con lo que incrementó notablemente el patrimonio de las comunidades cristianas, al tiempo que garantizaba su independencia económica y financiera ${ }^{74}$. A medida que crecían sus bienes, también lo hacían sus cargas. Las donaciones de los fieles estaban destinadas a aliviar las necesidades de viudas, huérfanos, pobres y desvalidos. Pronto, el evergetismo de la antigua elite gobernante empezó a canalizarse a través de la Iglesia, que recibía donaciones de las familias acomodadas y las repartía entre los necesitados. Con el ascenso de la autocracia imperial, las carreras de las elites locales y provinciales dependían cada vez menos de los honores que pudiesen dispensarles sus ciudades de origen y más de su proximidad a la corte. Muchos notables percibían ahora los actos de evergetismo como cargas e intentaban zafarse de ellas, bien aceptando la intervención de los agentes imperiales, bien delegando en los obispos cristianos. Al hacerlo, se limitaban a seguir las directrices trazadas por los emperadores cristianos, que habían dotado espléndidamente a la Iglesia, para que pudiese desempeñar funciones asistenciales. Como señala Constantino en una ley de 326 , "es preciso que los ricos asuman las obligaciones seculares y que los pobres sean socorridos con las riquezas de la Iglesia" $"$.

Con el tiempo, la jerarquía eclesiástica no sólo hubo de asumir funciones asistenciales, sino también administrativas y fiscales. En 409, el emperador Honorio (395423) dispuso que la elección del defensor civitatis, primer magistrado municipal, fuese llevada a cabo con la participación de los curiales, los grandes propietarios y senadores del lugar, y el obispo y su clero ${ }^{76}$. Poco después, en el transcurso de ese mismo año, otorgó a los prelados el derecho a supervisar las prisiones ${ }^{77}$. A esta última

71 Así se desprende del edicto de tolerancia promulgado por el emperador Galieno en 260 , disponiendo la restitución de los cementerios y lugares de culto confiscados a las comunidades cristianas durante la persecución de Valeriano; véase Eus. Hist. Eccl. VII, 13, ed. y trad. esp. A. Velasco-Delgado, 2 vols., $B A C$, Madrid, 1973.

72 Fue Galerio quien en 311 decretó en Sárdica el fin de la persecución de Diocleciano. Entre las medidas de gracia otorgadas a los cristianos, en aquel momento, se incluía el permiso de reconstruir sus lugares de reunión (Eus. Hist. Eccl. VIII, 17; LAct. De mort. persec. 34, ed. J. P. Migne, PL, 7, París, 1844, cols. 249-250). Para ello, era necesario que las iglesias recuperasen los bienes que les habían pertenecido. Tarea de la que se harían cargo los gobernadores provinciales. Al año siguiente, tras su victoria sobre Majencio, Constantino, en una carta dirigida a Anulino, gobernador del Âfrica Proconsular, dispuso la devolución de las propiedades confiscadas a las iglesias de la provincia (Eus. Hist. Eccl. X, 5, 15-17).

73 Eus. Hist. Eccl. X, 5, 1-14; LACT. De mort. persec. IV, 38, 2-12.

74 CTh. XVI, 2, 4, a. 321, ed. Th. Mommsen, Th. y P. Meyer, 2 vols., Berlín, 1905.

75 CTh. XVI, 2, 6, a. 326.

76 CJ I, 55, 8, a. 409.

77 Según CTh. IX, 3, 7, a. 409, el obispo debía velar por el bienestar de los detenidos, es decir, que no les faltase alimento y que pudiesen tomar un baño los domingos, y defender su causa ante los gobernadores provinciales. 
prerrogativa, que en 506 confirmaría el rey visigodo Alarico II (484-507) ${ }^{78}$, siguieron otras relativas al mantenimiento de las defensas y el patrimonio edilicio de la ciudad. Cuando en 395 Arcadio y Honorio decidieron que una tercera parte de las rentas procedentes de las tierras públicas se destinasen a reparar las murallas de las ciudades y calentar sus baños, las curias aún asumían la gestión de estas cargas ${ }^{79}$. Sin embargo, a fines del siglo $\mathrm{V}$, eran los obispos en colaboración con los funcionarios reales a cargo de las rentas del fisco, quienes se ocupaban de tales asuntos. Una inscripción procedente de Mérida, nos informa de cómo, en 483, el obispo Zenón, actuando conjuntamente con el dux Salla, enviado del rey Eurico (466-484), acometió la restauración del puente y las murallas de la ciudad ${ }^{80}$.

Diversos documentos legitiman esta transferencia de las funciones de gobierno, que en el pasado había ejercido la curia, al prelado de la iglesia local. Las Vitas Patrum Emeritensium incluyen un episodio, donde se narra cómo cierto primarius civitatis, del orden senatorial, transfirió su inmensa fortuna al obispo Paulo. A juzgar por los términos empleados, se trataba del epígono de una de esas familias aristocráticas de provincias, que ocupaban un puesto honorífico entre los principales de la curia y actuaban como patronos de la ciudad ${ }^{81}$. Según el relato, hallándose en peligro la vida de su esposa a causa de un parto dificultoso, acudió al obispo Paulo, que había ejercido como cirujano en el pasado. Éste practicó a la parturienta una cesárea y extrajo de su vientre el cuerpo de un niño muerto, consiguiendo salvarle la vida ${ }^{82}$. El matrimonio, en muestra de gratitud, decidió entregar al obispo la mitad de su fortuna en el acto, y el resto tras el fallecimiento de ambos. Como resultado, Paulo, que sobrevivió a los cónyuges, se convirtió en dueño de un patrimonio tan inmenso "que todos los recursos de la iglesia no eran nada en comparación con sus bienes" ${ }^{83}$. Años más tarde, toda la fortuna pasaría a la sede emeritense, que de este modo llegó a ser la más opulenta de Hispania ${ }^{84}$. El episodio aquí expuesto tiene el propósito de legitimar la riqueza y el poder patronal de la iglesia de Mérida, en base a una transferencia de bienes y honores del primarius civitatis al obispo, es decir, del miembro más destacado de la antigua elite gobernante a la cabeza de la jerarquía eclesiástica de la ciudad.

78 Brev. IX, 2, 3, a. 506.

79 CTh. XV, 1, 32, a. 395.

80 Vives, Inscripciones, $n^{\circ}$ 363. En Oriente se dio una evolución similar, aunque por razones bien distintas. A comienzos del reinado de Justiniano, era al obispo, en su calidad de delegado del soberano, a quien correspondía elaborar anualmente, con ayuda de tres primarii de la curia, un informe sobre las necesidades de su ciudad - entre ellas las relativas al combustible de las termas, el suministro de grano, la reparación de acueductos, puentes y fortificaciones-, para que los funcionarios imperiales pudieran proveerle de los fondos públicos precisos, cfr. $C J$ I, 4, 26, a. 530.

81 VPE IV, II, 1-2 : "Contigit cuiusdam primarii ciuitatis ex genere senatorum nobilissimi uiri egrotasse matrona, que et ipsa inlustri stigmate progenita nobilem traebat prosapiem. Que quum nupta in utero accepisset, ipse infantulus in uentre conlisus est ".

82 VPE IV, II, 3-12.

83 VPE IV, II, 15: "Tum deinde fecerunt de rebus suis talem conscriptionem ut de presentí sanctus uir medietatem ex omnibus que habebant acciperet, alia uero medietas post eorum obitum integra et intemerata ad eius pertineret dicione".

84 VPE IV, II, 18: “Quibus defunctis, omnem eorum patrimonium sanctissimus Paulus episcopus accipere Promeruit. Et qui peregrinus nicilque habens aduenerat factus est cunctis potentibus potentior en tantum ut omnis facultas eclesie ad comparationem bonorum illius pro nicilum putarentur". 


\section{SUCESIÓN Y CONFLICTO: EL EPISCOPADO DE FIDEL DE MÉRIDA}

La transferencia de poder y legitimidad operada en Mérida bajo el pontificado de Paulo no estuvo exenta de trabas. En principio, el prelado conservó la herencia recibida como parte de su patrimonio personal, de modo que no revirtió de manera inmediata en la iglesia. Es posible que de este modo, Paulo intentase afianzar su posición hegemónica frente a la crítica de cierto sector del clero. Por aquel entonces, nos refiere el autor de las Vitas, llegó a Mérida un grupo de mercaderes orientales, con quienes viajaba un adolescente llamado Fidel, hijo de una hermana del obispo. Paulo, tras comprobar la identidad del joven, decidió retenerlo junto a sí, y hacer de él su heredero y sucesor en la dignidad episcopa ${ }^{85}$. Enseguida, le consagró al servicio divino, imponiéndole la tonsura, y le instruyó personalmente en el oficio eclesiástico y en las Sagradas Escrituras. Más tarde, le promovió de grado en grado hasta alcanzar el diaconado y, finalmente, el presbiterado ${ }^{86}$. Cuando Paulo llegó a la vejez, eligió a Fidel como sucesor suyo:

"Después le ordenó que ocupase su lugar, aun estando él todavía con vida, y le instituyó heredero de todos su bienes, determinando mediante sanción testamentaria que, si el clero de Mérida quería tenerle como obispo, a su muerte legaría a la citada iglesia todas las posesiones que le había dejado; pero en otro caso, éste tendría libre potestad para determinar y decidir lo que quisiera sobre las citadas posesiones" ${ }^{\prime 87}$.

Aunque posiblemente se alzaran ya voces de protesta contra estas disposiciones anticanónicas, al final el clero de Mérida optó por someterse a la voluntad de Paulo y nombró a Fidel su sucesor en el episcopado. Cuando el anciano se sintió demasiado enfermo para atender a los oficios divinos, Fidel asumió las funciones propias de su cargo como obispo de la ciudad. Esta forma de sucesión hereditaria no era infrecuente en la Iglesia occidental de la época. Agustín había sido elegido obispo de Hipona por su predecesor Valeriano, mientras éste se hallaba aún vivo. Años más tarde, reconocería que su consagración había sido contraria al canon octavo del concilio de Nicea ${ }^{88}$. Y sin embargo, él mismo eligió como sucesor, durante los últimos días de su vida, al presbítero Heraclio, aunque nunca llegó a consagrarlo ${ }^{89}$. La práctica, considerada ya como irregular por el concilio de Antioquía del año $341^{90}$, sería condenada con firmeza en un sínodo romano celebrado el 19 de noviembre de 465 , del que se conserva un detallado protocolo ${ }^{91}$. Ante los 48 prelados asistentes, el papa Hilario reprobó la costumbre de ciertos obispos hispanos, que al aproximarse su última hora designaban sucesor. La denuncia del pontífice se basaba en una carta de Ascanio, metropolitano de la Tarraconensis, donde refería el caso de Nundinario

${ }^{85} V P E$ IV, III, 1-12.

${ }^{86} V P E \mathrm{IV}, \mathrm{IV}, 1 ; 6$.

${ }^{87} V P E$ IV, IV, 4, trad. esp. I. Velázquez, Madrid, 2008.

88 Poss. Vit. August. 8, ed. J. P. Migne, PL, 32, París, 1845; Aug. Ep. 31, 4, ed. y trad. esp. L. Cilleruelo, BAC, 3 vols, Madrid, 1987.

${ }^{89}$ Aug. Ep. 213, 4-5.

90 Conc. Ant. 23, ed. J. D., Mansi, SC, II, Florencia, 1759, cols. 1326-1327.

${ }^{91}$ Hilar. Ep. 1-3. 
de Barcelona. Hallándose éste en trance de muerte, había manifestado su voluntad de que le sucediese un tal Ireneo, a quien en el pasado había nombrado obispo de un municipio de su diócesis, con el oportuno consentimiento del propio Ascanio. Éste reconocía haber aprobado junto con todos los obispos tarraconenses la elección de Ireneo, en conformidad con los deseos y buen juicio de Nundinario. Al hacerlo, había tenido en cuenta la vida ejemplar y las virtudes del candidato, así como el hecho de que su promoción gozaba del apoyo del clero, el pueblo y los notables de Barcelona. Sin embargo, ninguna de estas razones persuadió a Hilario, que en su respuesta censura a los obispos de la Tarraconensis y particularmente al metropolitano Ascanio por haber consentido en una elección contraria a la disciplina canónica. Además, ordena que Ireneo regrese a su iglesia y se elija de entre las filas del clero de Barcelona un nuevo obispo para esta ciudad, "de modo que nadie crea que el honor del episcopado es un derecho hereditario".

Una carta del papa Hormisdas (514-523), dirigida a todos los obispos de Hispania el 2 de abril de 517, muestra que los problemas relacionados con las elecciones episcopales no habían cesado. Una vez más, el pontífice hubo de recordar que los obispos debían ser ordenados de acuerdo con las normas establecidas en los cánones. Era preciso que el elegido fuese un varón de vida irreprehensible, cuyas virtudes le hicieran merecedor de gobernar la iglesia y pastorear a la grey de Cristo. En ningún caso podían aspirar a la dignidad episcopal, ni laicos ni penitentes. Tampoco era lícito ordenar a nadie que pretendiese obtener el cargo a cambio del pago de fuertes sumas de dinero, pues la compra de dignidades eclesiásticas a menudo era semilla de todo tipo de discordias. Por último, Hormisdas reivindicaba para los fieles el derecho a participar en la elección de su obispo, ateniéndose a la máxima que decía: "en la voz poderosa del pueblo está el juicio de Dios"92.

No siempre las amonestaciones que llegaban de Roma se correspondían con los procedimientos empleados para proveer la cátedra de san Pedro. De hecho, la designación del nuevo pontífice por su predecesor en el cargo fue una práctica bien conocida, durante la primera mitad del siglo VI, en la sede romana. Uno de los episodios más célebres es el de Félix IV (526-530) y Bonifacio II (530-532). Puesto que el clero romano estaba dividió en facciones favorables a godos y bizantinos, el papa Félix intentó evitar que, tras su muerte, se produjese una doble elección, designando sucesor en vida. A tal efecto, reunió a un grupo de clérigos, senadores y patricios, y en su presencia impuso el pallium, símbolo de la autoridad pontificia, al archidiácono Bonifacio, amenazando con la excomunión a quien se negara a reconocerle como legítimo pontífice. La decisión de Félix no estaba exenta de implicaciones políticas. Bonifacio, de origen germano, contaba con el respaldo del rey ostrogodo Atalarico (526-534), nieto y sucesor de Teodorico el Grande (489-527), el mismo monarca que había promovido a Félix a la sede apostólica. El proyecto sucesorio del pontífice obtuvo también el apoyo del senado, que promulgó un decreto prohibiendo toda agitación electoral en vida del papa ${ }^{93}$. Ahora bien, en cuanto éste hubo fallecido, estalló el conflicto. Sesenta de los setenta presbíteros de la iglesia romana rehusaron

92 Horm. Ep. 25.

${ }_{93}$ El llamado Praeceptum Felicis y el Senatus consultum de 530 han sido editados por A. Hamman, PL Supp. 3, París, 1958-1974, cols. 1280-1281. 
reconocer la legitimidad de Bonifacio, inclinándose a favor de la candidatura del diácono Dióscoro, jefe de la facción bizantina, que se oponía a la creciente influencia de los godos. Ambos papas fueron consagrados el 22 de septiembre de 530, Bonifacio en la basílica de Julio y Dióscoro en la Lateranense. No duraría mucho la ruptura, ya que este último falleció veintidós días después. Preocupado por la posibilidad de que volviera a producirse una doble elección papal, en diciembre de 530 Bonifacio reunió un sínodo, ante el que presentó un decreto de anatema contra su difunto rival, exigiendo a los partidarios de Dióscoro que le prestasen juramento de obediencia ${ }^{94}$. En una segunda asamblea, convocada al año siguiente en la basílica de san Pedro, se arrogó mediante una constitución el derecho a elegir a su propio sucesor. El nombramiento recayó sobre la persona del diácono Vigilio. Esta vez, el clero y el senado, que se sentían privados del derecho a escoger a su obispo, hicieron causa común contra a Bonifacio, obligándole a convocar un tercer sínodo, donde hubo de quemar públicamente la constitución y revocar sus disposiciones sucesorias no canónicas. Aunque Vigilio no pudo acceder a la cátedra pontificia tras la muerte de Bonifacio, lo haría posteriormente, gracias al apoyo de la emperatriz Teodora ${ }^{95}$.

El nombramiento del obispo por su antecesor en el cargo podía generar graves conflictos. Así, a la muerte de Paulo de Mérida, una facción del clero local denunció la consagración irregular de Fidel, con objeto de expulsarle de la cátedra, en la que le había sido colocado su tío. Es posible que también se produjesen algaradas populares, como era habitual en estos casos. La presión llegó a ser tan intensa que el nuevo obispo amenazó con marcharse de la ciudad, llevándose la fortuna que había heredado. El temor a la pérdida económica apagó las protestas. Finalmente, se llegó a un acuerdo, en virtud del cual Fidel conservaría la dignidad pontificia, a cambio de que su patrimonio pasara a la iglesia de Mérida cuando falleciese. Llegado este momento, la sede metropolitana de la provincia de Lusitania "se enriqueció tanto que, en aquella época, ninguna iglesia era más rica que ella en los confines de Hispania"96. La estrecha dependencia de las iglesias locales respecto a la riqueza de sus obispos, explica el comportamiento del clero y el pueblo de Mérida. Las necesidades de financiación de un vasto programa de patrocinio, que incluía la construcción y restauración de grandes edificios y el mantenimiento de fundaciones piadosas y actividades caritativas, exigía que los obispos contribuyesen con su riqueza personal al sostén de la iglesia, a menudo legando todo su patrimonio a la misma en el momento de su muerte.

La elección de Fidel y su permanencia a la cabeza de la iglesia de Mérida, gracias a la posesión de una gran fortuna, no constituye un caso aislado en el panorama social de la época. Desde finales del siglo IV, el bienestar material de la población de las ciudades del mundo mediterráneo dependía cada vez más de la Iglesia. Este hecho explica que, en ocasiones, se eligiesen candidatos indignos, pero ricos y poderosos. El clero de la iglesia episcopal, que veía frustradas sus posibilidades de promoción con el nombramiento de un laico o de clérigo foráneo, solía demandar que las elecciones se ajustasen a la disciplina canónica; pero la gente común tenía otras prioridades. Lo

94 Para la fórmula de reconocimiento firmada por los antiguos partidarios de Dióscoro, véase $P L$ Suppl. 3, col. 1282.

${ }_{95}$ Lib. Pont. LVII; LX; LXI, ed.Th. Mommsen, MGH, GPR, Berlín, 1898.

96 VPE IV, V, 1-3; V, 3, 9. 
que realmente querían era un patrono que les brindase protección e intercediese por ellos ante los poderes superiores, tanto terrenales como celestiales. Por eso, se sentían inclinados a elegir o bien a un hombre santo, un monje o un eremita, cuya intercesión fuese realmente efectiva ante Dios; o bien a un hombre rico y con influencias en la corte del emperador o del rey bárbaro de turno. Osio de Córdoba denunció en el concilio de Sárdica de 343, la preferencia que manifestaban algunas iglesias por elegir como obispos a laicos, que destacaban por su poder, riqueza o brillante carrera en los tribunales y la administración ${ }^{97}$. Hacia el 401, Inocencio I lamenta en una carta dirigida a los obispos de Hispania que se otorgue la dignidad episcopal a antiguos magistrados municipales, cuyo único mérito consistía haber ofrecido al pueblo juegos y espectáculos circenses ${ }^{98}$. A veces, se produjeron ordenaciones forzosas de individuos ricos, como la del senador aquitano Paulino, a quien la plebe de Barcelona obligó a consagrarse al servicio de la Iglesia ${ }^{99}$. Algo semejante estuvo a punto de sucederle a Valerio Piniano en Hipona, donde se había refugiado tras el saqueo de Roma del 410; pero la hábil intervención del obispo Agustín, que relata el suceso en una de sus cartas, le permitió escapar a una ordenación no deseada ${ }^{100}$.

Por lo común, las iglesias contaban para su financiación con las ofrendas, donaciones y legados testamentarios de los fieles; pero estos ingresos rara vez eran suficientes para satisfacer todas sus necesidades. Se precisaba de la aportación de grandes fortunas, como la de Fidel, que pudiesen subvenir al mantenimiento de instituciones caritativas y edificios de culto, y al mismo tiempo asegurar la debida protección a la ciudad. El acuerdo alcanzado en Mérida entre el obispo Fidel, de una parte, y el clero y el pueblo, de otra, sólo se entiende en el marco de las relaciones sociales generadas por la creciente importancia del patrocinio de la Iglesia en la vida de las ciudades. Fidel, como se esperaba de un prelado de su posición, dedicó parte de su patrimonio personal a la construcción de magníficos edificios religiosos. Según refieren las Vitas Patrrum Emeritensium, levantó un nuevo palacio episcopal en sustitución del antiguo, que se había desplomado súbitamente un domingo por la mañana, poco después de que el obispo, acompañado del clero, de sus sirvientes y de una multitud de fieles, lo hubiese abandonado para oficiar la misa. Los muros y suelos de la nueva fábrica fueron revestidos de resplandecientes mármoles blancos. También restauró la basílica de santa Eulalia, construida hacia ya más de un siglo, añadiendo a su cabecera dos torres, a fin de defender el recinto, ubicado en un suburbio de Mérida y, por lo tanto, expuesto a posibles asaltos ${ }^{101}$.

Cuando Paulo decidió elegir un sucesor en vida, vulnerando la disciplina canónica, no optó por un clérigo de su iglesia, como hicieron otros prelados de la época, sino que escogió a su propio sobrino. De este modo convirtió la sede de Mérida en el centro de una nueva dinastía episcopal de origen bizantino. La presencia de este tipo de familias, que se perpetuaban por vía hereditaria en ciertas cátedras episcopales,

\footnotetext{
${ }^{97}$ Conc. Sard. XIII.

98 Inoc. I Ep. III, 4.

99 Aug. Ep. 24, 4.

100 Ibid. 126, 1-7.

101 VPE IV, VI, 7-8.
} 
se haya bien documentada para el período tardorromano y visigodo ${ }^{102}$. El caso más célebre es el de los hijos de Severiano, notable hispanorromano oriundo de Carthago Spartaria. El mayor, Leandro, llegó a ser obispo de Sevilla (ca. 579-599), siendo sucedido, tras su muerte, en la cátedra metropolitana de la Baetica por su hermano menor Isidoro (ca. 599-636). Un tercer hermano, Fulgencio, fue obispo de Astigi (Écija) y una hermana, Florentina, abadesa de una comunidad de vírgenes ${ }^{103}$. El hecho de formar parte de una de las más prestigiosas dinastías sacerdotales de la Hispania del siglo VI, no impidió que Isidoro incluyese, entre los que acceden de forma irregular al episcopado, a todos aquellos que "hacen sucesores a sus hijos o parientes"104.

Por lo común, estas familias combinaban dos estrategias de dominio territorial. Una consistía en transmitir ciertas sedes episcopales de padre a hijo o entre hermanos, durante varias generaciones; y la otra en colocar a distintos miembros del grupo a la cabeza de dos o tres sedes de una misma región, de modo que todos ellos gobernasen simultáneamente. En tiempos del rey Teudis (531-548) una de estas familias, la del obispo Justo de Urgel, logró controlar una extensa zona de la Tarraconensis. Sus tres hermanos, Elpidio de Huesca, Nebridio de Egara y Justiniano de Valencia alcanzaron la dignidad episcopal ${ }^{105}$. Si se exceptúa la sede de este último, las de los otros tres hermanos forman un triángulo, que define los límites de una amplia región, situada entre la costa catalana y los Pirineos, donde esta familia ejercía su poder. Una tercera saga de obispos, ya en el siglo VII, la forma Juan de Zaragoza, que rigió esta sede de 619 a 531, y su hermano y sucesor, Braulio, que la gobernó entre 631 y 651. El epitafio de Juan, redactado en verso por Eugenio de Toledo, recuerda que también su padre Gregorio había sido obispo ${ }^{106}$. Se desconoce qué iglesia presidió, aunque a veces se le ha identificado con cierto Gregorio de Osma, que suscribió la constitución promulgada por el sínodo de la provincia Carthaginensis, bajo el reinado de Gundemaro $^{107}$.

La aparición de las primeras familias episcopales parece remontarse a los últimos tiempos del Imperio. Pero fue a partir de mediados del siglo V, cuando las elites provinciales hispanorromanas desembarcaron en la Iglesia, dispuestas a perpetuar el poder que habían ejercido durante generaciones, asumiendo el gobierno de las ciudades desde la dignidad episcopal. Algunas familias formaron auténticas dinastías sacerdotales, cuyos miembros ocupaban las principales sedes de la región donde se concentraba su patrimonio y sus relaciones clientelares. De padre a hijo, de hermano a hermano, o de tío a sobrino, ciertas cátedras, como la de Mérida, Sevilla o Zaragoza, se trasmitieron en el interior de un mismo grupo de parentesco durante dos o más

102 Sobre las dinastías episcopales o familias sacerdotales hispanas, véase Díaz y Díaz, M. C., "Introducción general", Isidoro de Sevilla. Etimologias, ed. y trad. esp. J. Oroz Reta y M. Marcos Casquero, BAC, Madrid, 1982, pp. 102; Orlandis, J., La vida en España en tiempos de los godos, Madrid, 1991, pp. 31-32; Teja, R,: "Las dinastías episcopales en la Hispania tardo-romana", Cassiodorus, 1, 1995, pp. 29-39.

103 Leand. Reg. XXXI, ed. y trad. esp. J. Campos Ruíz y I. Roca Melia, BAC, Madrid, 1971; Isid. De Vir. Illustr. XXVIII.

${ }^{104}$ Isid. De Eccl. Off. II, 5, 13, Migne, PL, 83, París, 1850, col.784.

${ }^{105}$ Id. De Vir. Illustr. XX-XXI.

106 Eug. Tol. Carm. XXI.

107 Vives, Concilios, p. 29. 
generaciones, acrecentando la autoridad de sus titulares. Hubo familias sacerdotales, como la de origen greco-oriental instaurada por el obispo Paulo en la sede de Mérida, que no gozaban de arraigo en la región. Sin embargo, supieron construir su legitimidad sobre ceremoniales de poder y programas de patrocinio, que ampliaron las redes clientelares y el prestigio de las iglesias que presidían. El cese de la continuidad dinástica, como el que se produjo en Mérida a la muerte de Fidel, rara vez suponía una ruptura con el pasado. Los nuevos obispos procuraban vincularse a sus predecesores mediante lazos de parentesco simbólico, pasando así a formar parte de la cadena de pastores espirituales, que debían guiar al pueblo hasta el fin de los tiempos. 